\title{
天竜川上流および三峰川の堤防法面におけるチガヤマッ 卜設置の効果
}

\section{水沼 薰 ${ }^{* 1}$ ) - 木村保夫 1) - 佐藤 靖 2)}

1）エスペックミック株式会社

2）国土交通省天竜川上流河川事務所

摘要 : 一級河川天竜川および三峰川の一部の堤防では, オオキン ケイギク (Coreopsis lanceolata) が優占し，これが堤防の裸地化 と浸食の原因となっている。そこでオオキンケイギクの侵入を抑 制し安定した堤防植生を形成させるため，チガヤ（Imperata cylindrica) のマット状苗（チガヤマット）を設置し観察を行った。 その結果, 設置からおよそ半年で堤防法面はチガヤが優占する植 生が形成された。この間，堤防法面の浸食は認められなかった。 設置から 1 年後には根茎由来のオオキンケイギクが若干確認され たが，種子由来による侵入は認められていない。

キーワード : チガヤ，オオキンケイギク，堤防植生

\section{1. はじめに}

一級河川天竜川および三峰川の一部の堤防では, キク科の 多年草であるオオキンケイギクが優占した植生が形成されて いる。一般に堤防法面には築堤時に張芝が行われるが，才オ キンケイギクが侵入しロゼット状の葉を展開すると, その下 になった芝は枯死してしまう。さらに除草管理による刈り取 りが行われると, 法面にはオオキンケイギクによって形成さ れた多数の裸地が生じる。天竜川水系ではこれらの裸地に起 因した堤防法面の浸食が問題となっている。その一方で，一 部の堤防法面ではイネ科の多年生草本であるチガヤの優占す る植生が認められており, こうした植生にはオオキンケイギ クはほとんど生育していないことが観察された。

そこで我々は浸食の発生しない安定した植生を形成するこ とを目的に，張芝に替わる植物としてチガヤを導入し，堤防 法面の緑化とオオキンケイギクの侵入抑制の効果について調 査を実施した。

\section{2. 調查地}

調査は長野県伊那市西春近の天竜川 $186.6 \mathrm{~km}$ 地点の堤防 法面と伊那市富県の三峰川 $3 \mathrm{~km}$ 地点とした（図-1）。

\section{3. 材料ならびに方法}

チガヤによる緑化には種子吹付け，苗の植栽，マット状苗 の設置などがあるが，このうち種子吹付けは発芽時の水管理 が困難で，時期を選ぶなどの難点があり成功する確率が低い 1)。また苗の植栽は，植栽直後に苗と苗の間に裸地が生じる ため初期の浸食が問題となる。天竜川ではオオキンケイギク に起因する堤防の裸地化と浸食が問題であることから，今回 は速やかな緑化と浸食が生じにくい方法として, マット状苗 (以下チガヤマット) を用いることとした。チガヤマットは ヤシ緎維基盤上にあらかじめチガヤが育成されたものである (写真-1)。

チガヤマットの設置は天竜川と三峰川の両調査地で行っ た。以下，それぞれの試験区について記す。

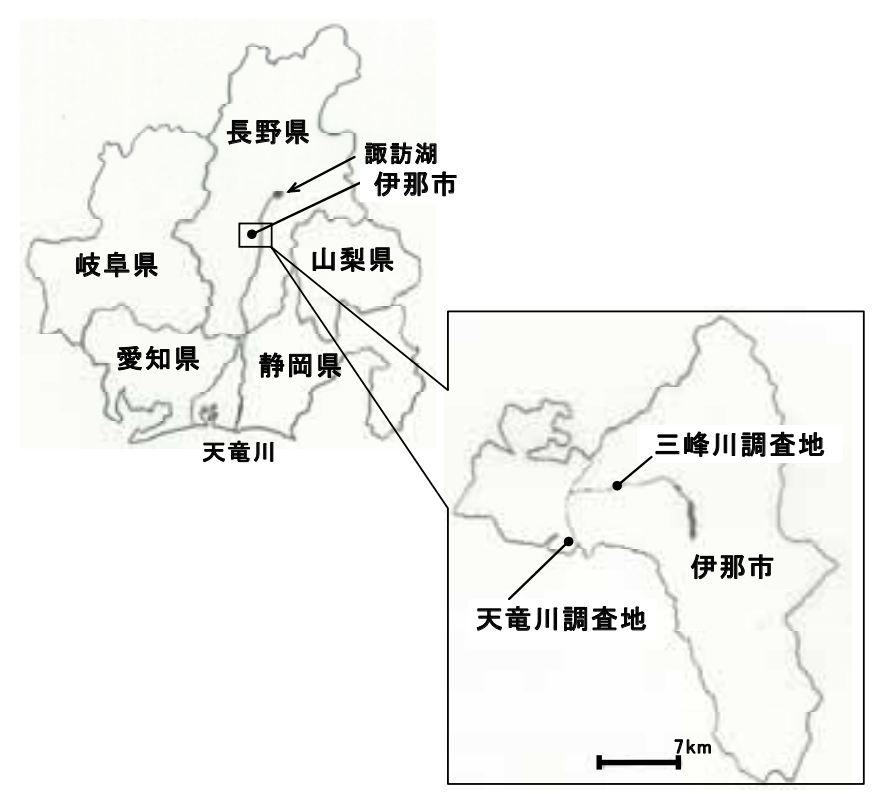

図-1 天竜川および三峰川調査地

\footnotetext{
* 連絡先著者: E-mail : k-mizunuma@especmic.co.jp $\overline{\bar{T}} 480-0141$ 愛知県丹羽郡大口町大御堂 1-233-1
} 


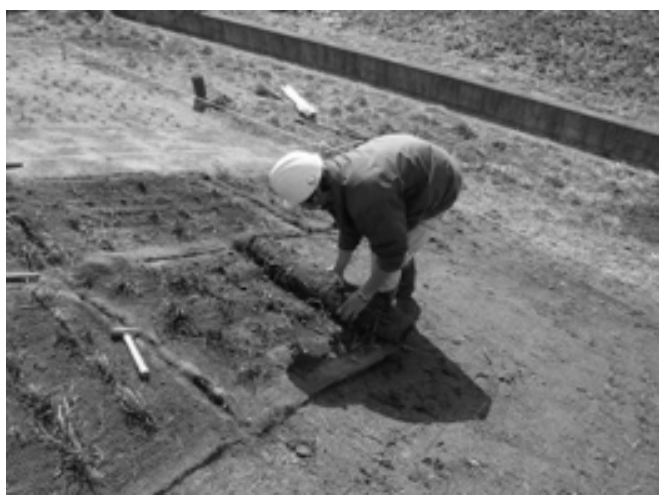

写真-1 チガヤマットの敷設状況

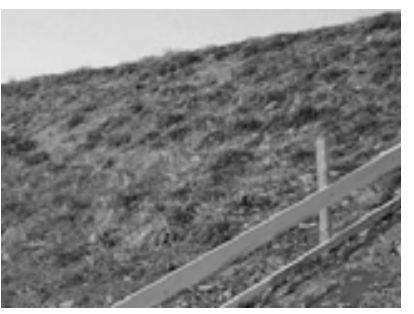

写真-2 チガヤマット設置前 の堤防法面の状況 (写真奥)

\section{1 天竜川}

平成 21 年 3 月 23 日に平成 20 年度天竜川駒ヶ根地区堤防 維持管理工事において，380 m²にチガヤマット（幅 $0.58 \mathrm{~m}$ ×長 $1.8 \mathrm{~m}$ ）を設置した。写真-2 および写真-3のように天竜 川の堤防法面はオオキンケイギクが優占しており，堤体はか なり浸食されていたので, 早急な対策が必要とされていた。 そのため, チガヤマットの設置に先立ち, 堤防法面の表土を $30 \mathrm{~cm}$ 剥ぎ取り，オオキンケイギクの種子の混入が無いと考 えられる山土が客土された。

調査は平成 21 年の 5 月， 6 月， 8 月および 10 月に，目視 による全体の植被率の測定，特筆す心゙き植物の記録および定 点写真撮影を行った。

\section{2 三峰川}

平成 21 年 3 月 16 日に三峰川堤防（伊那市富方地内）にお いてチガヤマット（幅 $1.2 \mathrm{~m} \times$ 長 $1.8 \mathrm{~m}$ ）を設置した。5つの 試験区を設け， 5 月と 8 月に地際から刚取りを行う 2 回刚取 り区，5月のみに刈取りを行う 1 回刘取り区，刈取りを行わ ない刚取り無し区，野芝を張った張芝区および既存堤防を対 照区とした（図-2）。それぞれの試験区に永久方形区を $3 つ$ ずつ設置し, 草高, 被度, 出現種などを記録するとともに, 定点写真の撮影を行った。被度, 群度はBraun-Blanquet の 優占度階級および群度の階級に従った ${ }^{2)}$ 。得られたデータか ら, 以下の式で積算優占度を算出した。比数とは得られたデ ータの最高值を 100 とした場合の相対值である。

積算優占度 $=$ (草高比数 + 被度比数 $) \div 2$

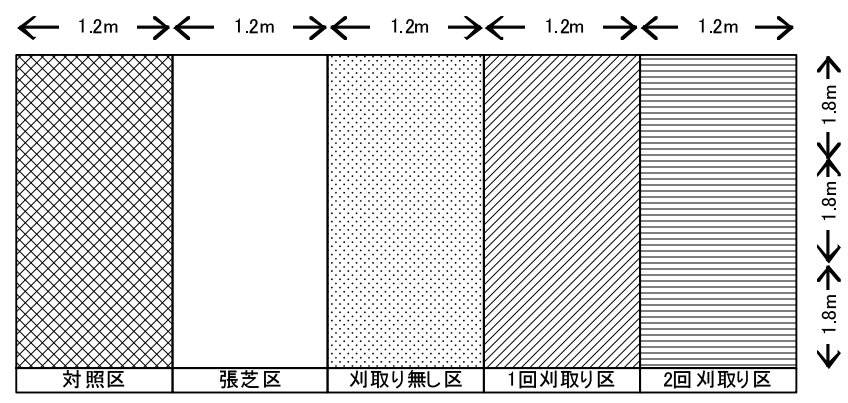

図-2 三峰川試験区設定

\section{4. 結果}

\section{1 天竜川}

図-4 から図-7 にチガヤマットを設置した法面の緑化状況 を示す。

チガヤマットの設置からおよそ 4 ケ月後の平成 21 年 8 月 には法面の植被率はおよそ $90 \%$ に達した（図-3）。この時点 で生育が認められたのはチガヤとともにメヒシバ, エノコロ グサ，イヌビエなどのイネ科の一年生草本も多く認められた (写真-5）。8月下旬に堤防の除草管理が行われたが，10月 時点では，チガヤが速やかに伸長している状況を確認するこ とができた（写真-6）。メヒシバなどのイネ科一年生草本は 攪乱された土地にいち早く侵入するが，翌年にはその発生は 減少寸るため, 翌年にはチガヤが優占した植生となることが 予想される。

図-3に示寸ように 6 月から 8 月にかけて植被率が急速に高 くなっている。これは, 腹付けに用いられた山土にほとんど 養分が無かったため, 全般的に植物の生育が悪く, チガヤの 生育を促すために 6 月と 7 月に $60 \mathrm{~g} / \mathrm{m}^{2}$ の施肥を行ったこと によるものである。チガヤは砂質土から粘性土まで幅広い土 㙵条件で生育することができるため，通常は施肥は行わなく ても十分に生育が可能である。しかし試験区は著しく養分の 少ない山土でチガヤの生育がかなり遅くなったため, 今回は 本調査の目的を鑑みて施肥を行い，チガヤ群落を早期に形成 させることとした。その結果, およそ 1 年で堤防法面にチガ ヤ群落を創出させることが出来た。この期間における法面の 浸食は認められなかった。

今回の試験区ではオオキンケイギクが 3 株確認されたが, その株の大きさから，種子によるものではなく表土剥ぎ取り 時に残った根茎に由来するものといえる（写真-7）。試験区 の周囲にはオオキンケイギクが多数生育しているが，施工か らおよそ 1 年経過した平成 22 年 5 月 14 日時点でも種子に由 来するオオキンケイギクの侵入は認められていない。今後, チガヤ群落内の根茎由来のオオキンケイギクの成長と裸地形 成状況についてモニタリングすることで，天竜川における堤 防法面を保護する上で有効な緑化手法についてさらなる知見 が得られると考えられる。 


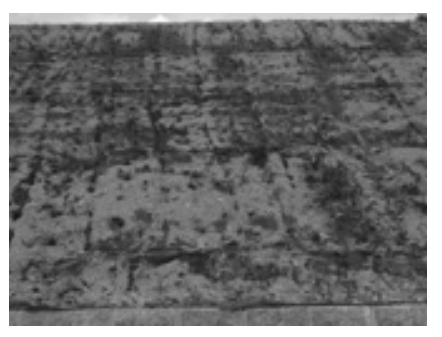

写真-4 平成 21 年 6 月 17 日 の状況

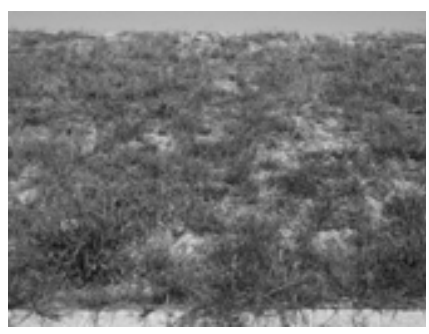

写真-6 平成 21 年 10 月 19 日 の状況

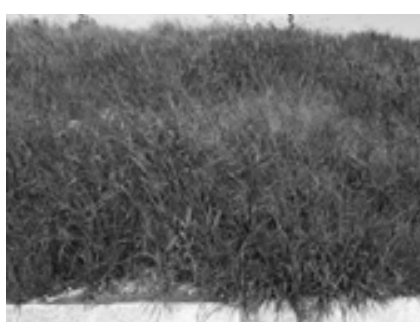

写真 -5 平成 21 年 8 月 18 日 の状況

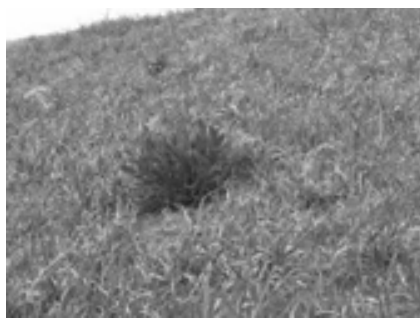

写真-7 平成 22 年 5 月 14 日 の状況

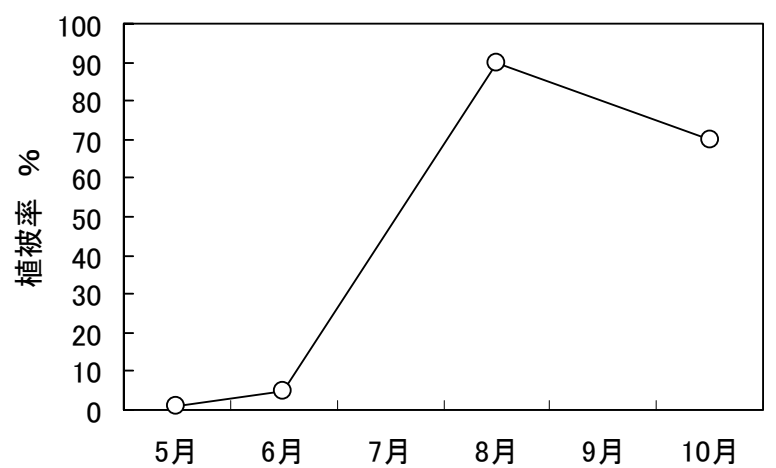

図-3＼cjkstart植被率の変化

\section{2 三峰川}

三峰川では，ヒロ八ホウキギクやオオアレチノギクなどの 高茎の雑草が侵入したものの, チガヤの生育は良好であった （図-4〜図-6）。チガヤは刚り取り回数にかかわらず，春か ら秋にかけて被度の上昇が認められた（図-7）。試験開始後, 様々な植物の侵入が認められ，2 回刈取り区，1 回刈取り区 および刚取り無し区で 23 種が認められた。オオキンケイギ クも 1 株確認されたが，その大きさから根茎に由来するもの であると考えられる。また，各試験区ではヒレハリソウが多 く認められたが，堤防の張芝に侵入したオオキンケイギクの 場合と同様に, 幅広いヒレハリソウの葉の下では芝が枯死し ている状況が確認された（写真-8）。これに対し，チガヤマ ットを設置した試験区でもヒレハリソウが葉を展開していた が，チガヤはヒレハリソウの葉の隙間から葉を伸長させてい る状況が確認された（写真-9）。この間, 試験区における法
面の浸食は認められなかった。

一方で対照区は，春から秋にかけてオオキンケイギクが優 占し（図-8，写真-10），秋から冬にかけては植生がほとんど 無い礫が剥きだしの状況で，浸食がかなり進行した状況であ った（写真-11）。

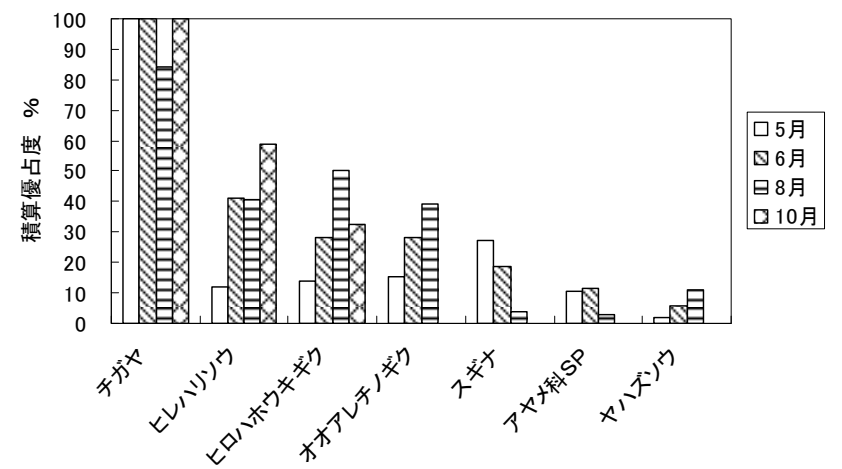

図-4 2 回刈取り区の積算優占度（3 回以上出現した種）

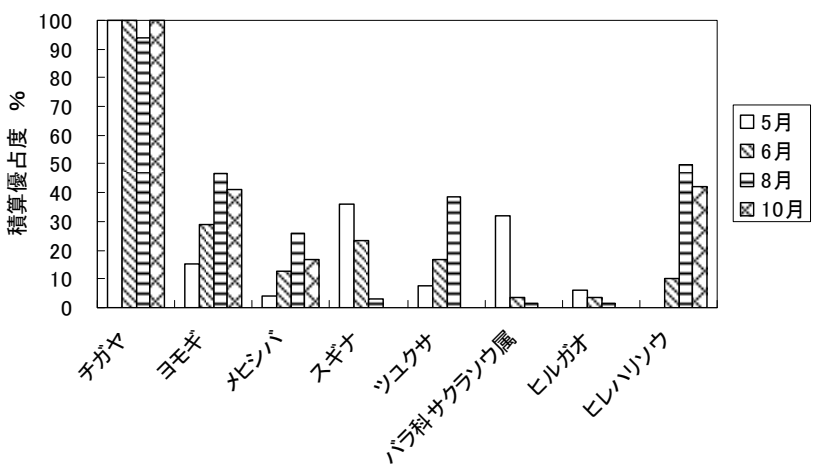

図-5 1 回刚取り区の積算優占度（3 回以上出現した種）

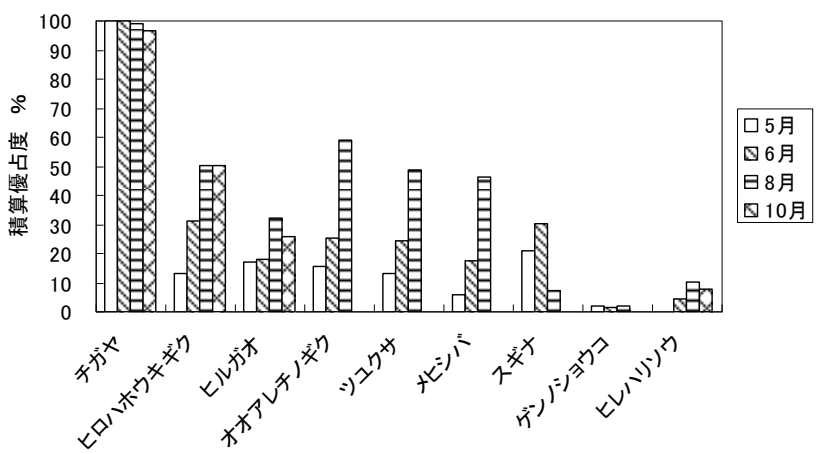

図-6 刈取り無し区の積算優占度（3 回以上出現した種） 


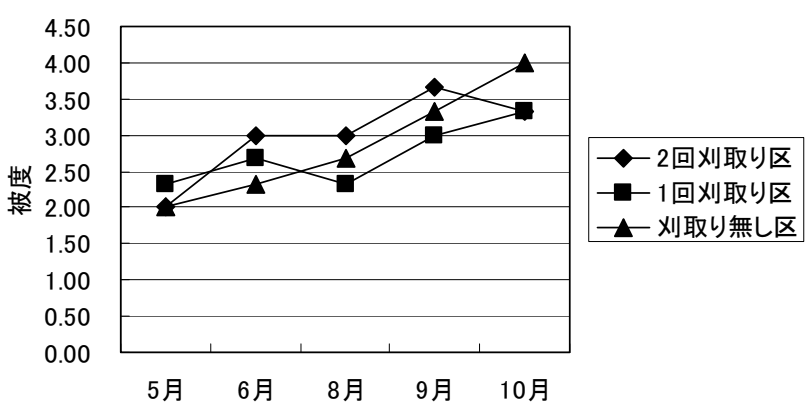

図-7 各試験区のチガヤの被度の変化

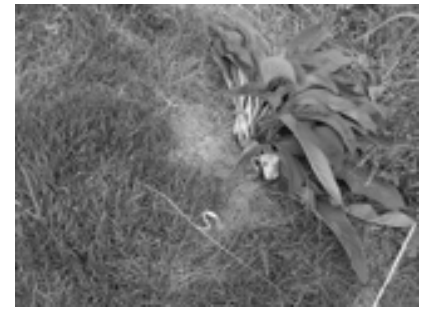

写真-8 張芝区に侵入したヒ レハリソウ

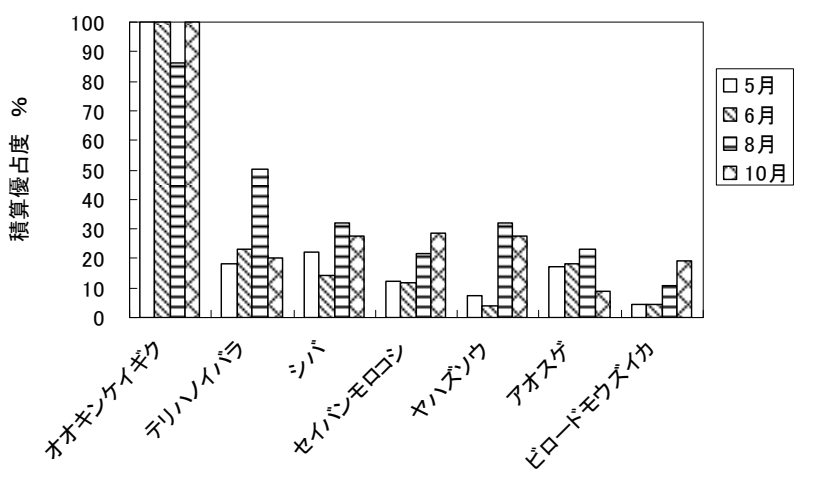

図-8 対照区の積算優占度（3 回以上出現した種）

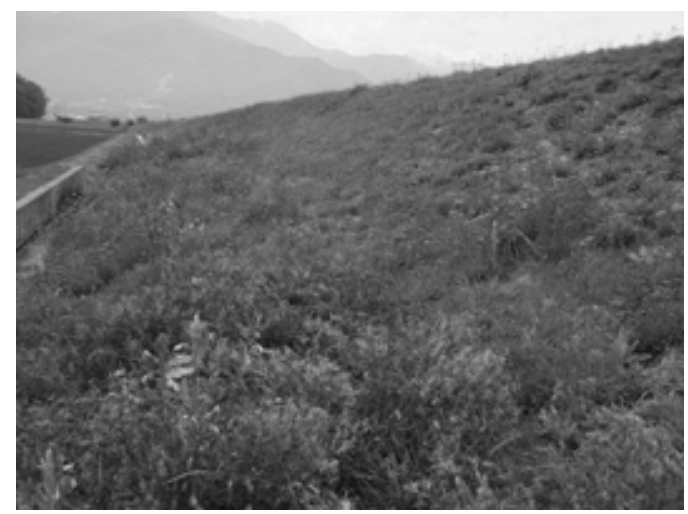

写真-10 平成 21 年 6 月 17 日の状況

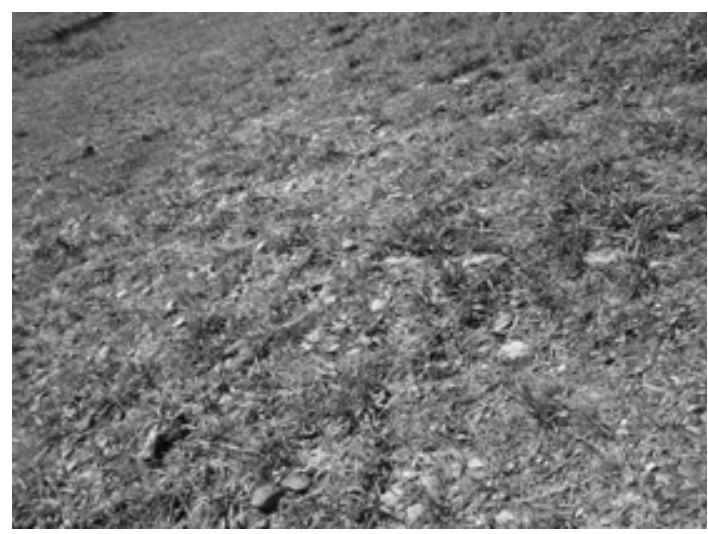

写真-11 平成 21 年 11 月 18 日の状況

\section{5. まとめ}

天竜川ではチガヤマットの設置によりおよそ半年でチガヤ を主体とした堤防植生を創出することができた。三峰川では, 高茎草本や広葉型草本の侵入があっても，チガヤは衰退する ことなく生育することを確認することができた。一方, 両調 査区ともに，若干数ではあるが，根茎由来と思われる才オキ ンケイギクの侵入が見られた。しかし，才オキンケイギクの 侵入に起因寸る堤防法面の浸食は認められなかった。

今回はオオキンケイギクに着目して調査を実施したが，三 峰川の調査から明らかなように，ヒレハリソウなどの広葉型 草本でも堤防法面の浸食の原因となる可能性が示唆されてい る。天竜川および三峰川では築堤材料は河川の砂碩が用いら れた経緯があり，こうした堤防の土壌条件がオオキンケイギ クの生育条件を満たし, 裸地が形成されると直ちに浸食が生 じる一因となっている可能性がある。築堤材料はその地域固 有の条件があるため変更することは困難であるが, 法面緑化 に用いる植物は，それぞれの地域の課題に応じた種を柔軟に 適用することが可能である。今回は張芝の替わりにチガヤを 用いたが，今後チガヤはオオキンケイギクやヒレハリソウな どの広葉型草本による裸地形成を効果的に抑制することが期 待できる。オオキンケイギクは外来生物法により特定外来生 物に指定されているが，今回のこの試験から，オオキンケイ ギクの堤防法面への侵入定着を効果的に抑制することが可能 となれば, 在来生態系の保全に応用することも可能となるで あろう。

\section{引用文献}

1）チガヤ草原創出研究会（2000）チガヤ草原創出の手引き, 建 設省近畿地方建設局姫路工事事務所, pp. 17-27.

2）財団法人国際生態学センター（1995）環境保全林形成のため の理論と実践, 財団法人国際生態学センター, pp. 18.

(2010. 7.24 受理) 